\title{
Association of Interleukin-10 -1082A>G (rs1800896) Polymorphism with Predisposition to Breast Cancer: a Meta-Analysis based on 17 Case- Control Studies
}

\author{
Mostafa Abedinzadeh ${ }^{1}$ \\ Hossein Neamatzadeh ${ }^{2}$ \\ Mohammadali Jafari ${ }^{3}$ \\ Mohammad Forat-Yazdi ${ }^{4}$ \\ Rezvan Nasiri ${ }^{5}$ \\ Soudabeh Farahnak ${ }^{6}$ \\ Elnaz Foroughi ${ }^{7}$ \\ Masoud Zare-Shehneh ${ }^{8}$
}

\begin{abstract}
1. Department of Internal Medicine, Kashan University of Medical Sciences, Kashan, Isfahan, Iran 2. Mother and Newborn Health Research Center, Shahid Sadoughi University of Medical Sciences, Yazd, Iran 3. Department of Emergency Medicine, Shahid Sadoughi University of Medical Sciences, Yazd, Yazd, Iran 4. Department of Internal Medicine, Shahid Sadoughi University of Medical Sciences, Yazd, Yazd, Yazd, Iran

5. Department of Restorative and Esthetic, Arak University of Medical Sciences, Arak, Markazi, Iran 6. Department of Endodontic, Arak university of Medical Sciences, Arak, Markazi , Iran 7. Department of Pediatric Dentistry, Arak university of Medical Sciences, Arak, Markazi, Iran 8. Department of Medical Genetics, Shahid Sadoughi University of Medical Sciences, Yazd, Yazd, Iran
\end{abstract}

http://dx.doi.org/10.1590/1806-9282.64.08.756

\section{SUMMARY}

INTRODUCTION: The association between the between IL-10 -1082A>G (rs1800896) polymorphism and breast cancer has been evaluated by several number case-control studies. However, these studies might be underpowered to reveal the true association.

OBJECTIVE: We have performed a comprehensive meta-analysis to investigate the association IL-10 -1082A>G polymorphism and breast cancer.

MATERIALS AND METHODS: A systematic literature search was conducted using PubMed, Google Scholar, and Web of Science up to September 20, 2017. Data was analysed with CMA software to identify the strength of the association by pooled odds ratios (ORs) with corresponding 95\% confidence intervals (Cls).

RESULTS: A total of 17 case-control studies involving 3275 cases and 3416 controls obtained from database searches were examined. Overall, there was no significant association between IL-10-1082A $>$ G polymorphism and breast cancer risk under all genetic models. No significant publication bias was found for the five genetic models ( $G$ vs. A: $O R=1.184,95 \% \mathrm{Cl}=0.895-1.180, p=0.230 ; G G$ vs. AA: $O R=1.430,95 \% \mathrm{Cl}=0.927-2.204, p=0.106 ; \mathrm{GA}$ vs. $A A: O R=0.966,95 \% \mathrm{Cl}=0.765-1.221, p=0.774 ; \mathrm{GG}+\mathrm{GA}$ vs. $\mathrm{AA}: \mathrm{OR}=0.957,95 \% \mathrm{Cl}$ $=0.697-1.314, p=0.786$; and GG vs. GA+AA: $O R=1.221,95 \% \mathrm{Cl}=0.981-1.518, p=0.073)$. Moreover, there was no significant association between the IL-10-1082A>G polymorphism and breast cancer risk by ethnicity.

CONCLUSION: Our findings indicated that IL-10 -1082A>G (rs1800896) polymorphism might not be a risk factor for the development of breast cancer.

KEYWORDS: Breast neoplasms. Interleukin-10. Polymorphism, genetic. Meta-analysis. 


\section{INTRODUCTION}

Breast cancer is one of the most commonly diagnosed invasive malignancies. ${ }^{1-3}$ Breast cancer is the second most common cancer-related death in women worldwide and accounts for $15.4 \%$ of cancer-related deaths in women. ${ }^{4,5}$ The pathogenesis of breast cancer is multifactorial. Hereditary breast cancer accounts for only $5-10 \%$ of all breast cancer cases and germline mutations with the two major breast cancer susceptibility genes BRCA1 and BRCA2, being responsible approximately for $2-3 \%$ of all cases ${ }^{6,7} \mathrm{Be}-$ sides gene tests to identification of high-risk BRCA1 or BRCA2 mutations carriers, the ability to predict breast cancer development, is not well established yet. $^{7,8}$ The findings suggest that accumulation of several polymorphic variants is responsible for elevated risk of breast cancer. ${ }^{9,10}$ However, the association of genetic variations with the clinical characteristics and prognosis in breast cancer has not been fully identified."

The human interleukin 10 gene is a steroid hormone receptor gene located on chromosome 6 at 6q25.1. It contains eight exons spanning $295 \mathrm{~kb}^{12,13}$ The IL-10 promoter is highly polymorphic and three most common SNPs, including -1082, -819, and -592, within this region have been correlated with IL-10 production. ${ }^{14}$ Several epidemiological studies have evaluated IL-10 -1082 polymorphism and its association with breast cancer. ${ }^{15-21}$ However, the effects of polymorphisms in rs2077647, rs2228480 and rs3798577 were also controversial. It is clear that the number of studies, time of analysis and new studies included in a meta-analysis directly influences the credibility and stability of the findings. Therefore, we have performed this systematic review and meta-analysis to more accurately assess the association between IL-10 -1082A>G (rs1800896) polymorphism and breast cancer risk, using more recent published studies.

\section{MATERIALS AND METHODS}

\section{Search Strategies}

A computerized literature search of different databases, including PubMed, Web of Science, EMBASE, China National Knowledge Infrastructure (CNKI), China Biology Medicine (CBM) and Google Scholar was conducted up to September 20, 2017. The search strategy identified all possible studies using combinations of the following terms and keywords:
'Breast cancer", 'interleukin 10", 'IL-10 gene”, '”1082A>G", "rs1800896”, "polymorphism", "variant" and "mutation". Furthermore, we have manually screened the bibliographies of relevant articles and reviews for additional studies that were not captured by the database search. Publications in both English and Chinese languages were included, and only published studies with full-text articles were included.

\section{Inclusion and Exclusion Criteria}

The studies included in this meta-analysis had to meet the following criteria: (1) any study published as a case-control or cohort study that evaluated the association between IL-10 -1082A>G (rs1800896) polymorphism and breast cancer risk; (2) the numbers of cases and controls for each genotype were reported or sufficient data was provided to calculate the odds ratio (OR). The following were exclusion criteria: (1) not designed as case-control or cohort studies, (2) reviews, abstracts or animal studies; (3) studies were not relevant to IL-10 -1082A >G (rs1800896) polymorphism and breast cancer; (4) not providing the genotype frequencies; and (5) duplicate of previous publication. If multiple studies from the same case series were available, the one including the most individuals was used in the analysis.

\section{Data Extraction}

The information was carefully extracted from all of the eligible studies independently by two investigators based on the inclusion criteria listed above and then examined by an expert in headaches. From each of the included articles the following data were collected: first author, year of publication, country of origin, ethnicity, total number of cases and controls, frequencies of genotypes, genotyping technique, minor allele frequencies (MAFs), P-value for HardyWeinberg equilibrium (HWE). In case of disagreement, consensus was obtained on every item by joint review of the study. The different ethnic descents were categorized as Asian, European, American or African.

\section{Statistical Methods}

The odds ratio (OR) and its 95\% confidence inter$\mathrm{val}(\mathrm{CI})$ was used to assess the strength of association between IL-10 -1082A>G (rs1800896) polymorphism and breast cancer risk under allele model (G vs. A), homozygote model (GG vs. AA), heterozygote model (GA vs. AA), dominant model (GG+GA vs. AA), and 
recessive model (GG vs. GA+AA). The significance of the pooled OR was determined by the Z-test. Heterogeneity assumption was checked by the Chi-squarebased Q-test. ${ }^{22}$ The effect of heterogeneity was quantified using the $\mathrm{I}^{2}$ value as well as $\mathrm{P}$ value. A P-value less than 0.10 for the Q-test and $\mathrm{I}^{2}$ value $>50 \%$ indicates existence of heterogeneity among studies. The pooled OR was assessed in both fixed-effects model (the Mantel-Haenszel method) ${ }^{23}$ and random-effects model (the DerSimonian and Laird methods), ${ }^{24}$ so the pooled OR estimates of the included studies was calculated by the random-effects model. Otherwise, the fixed-effects model was used. Sensitivity analyses were performed to evaluate the stability of the results, namely, a single study in the meta-analysis was omitted in each turn to reflect the influence of the single data set on the pooled results. Deviation from the Hardy-Weinberg equilibrium (HWE) was checked among controls through exact test. Subgroup analyses by ethnicity and studies quality were performed subsequently. Begg's funnel plot was carried out to examine the potential publication bias between studies ( $\mathrm{P}$ value less than 0.10 was selected to be statistically significant). ${ }^{25}$ In addition, Egger's test on the natural logarithm scale of the OR was used to estimate the funnel plots asymmetry. ${ }^{26}$ All statistical analyses were performed using Comprehensive Meta-Analysis (CMA) software version 2.0 (Biostat, USA). All $\mathrm{P}$ values were two-sided, and $\mathrm{P}<0.05$ was considered statistically significant.

\section{RESULTS}

\section{Characteristics of Selected Studies}

We have identified 211 published case-control studies before September 20, 2017 in the database search and by manual screening. Of these studies, the first screening excluded 109 publications that were excluded as duplicates or not relevant, leaving 102 studies for further selection. After removal of review articles, case reports, and those that did not meet our inclusion criteria, a total of 17 articles 4,12,13,15-21,27-33 with 3,275 cases and 3,416 controls were finally included in our meta-analysis. A flow diagram schematizing the inclusion and exclusion process of identified articles with the inclusion criteria is pre-

FIGURE 1. FLOW CHART OF LITERATURE SEARCH AND STUDY SELECTION.

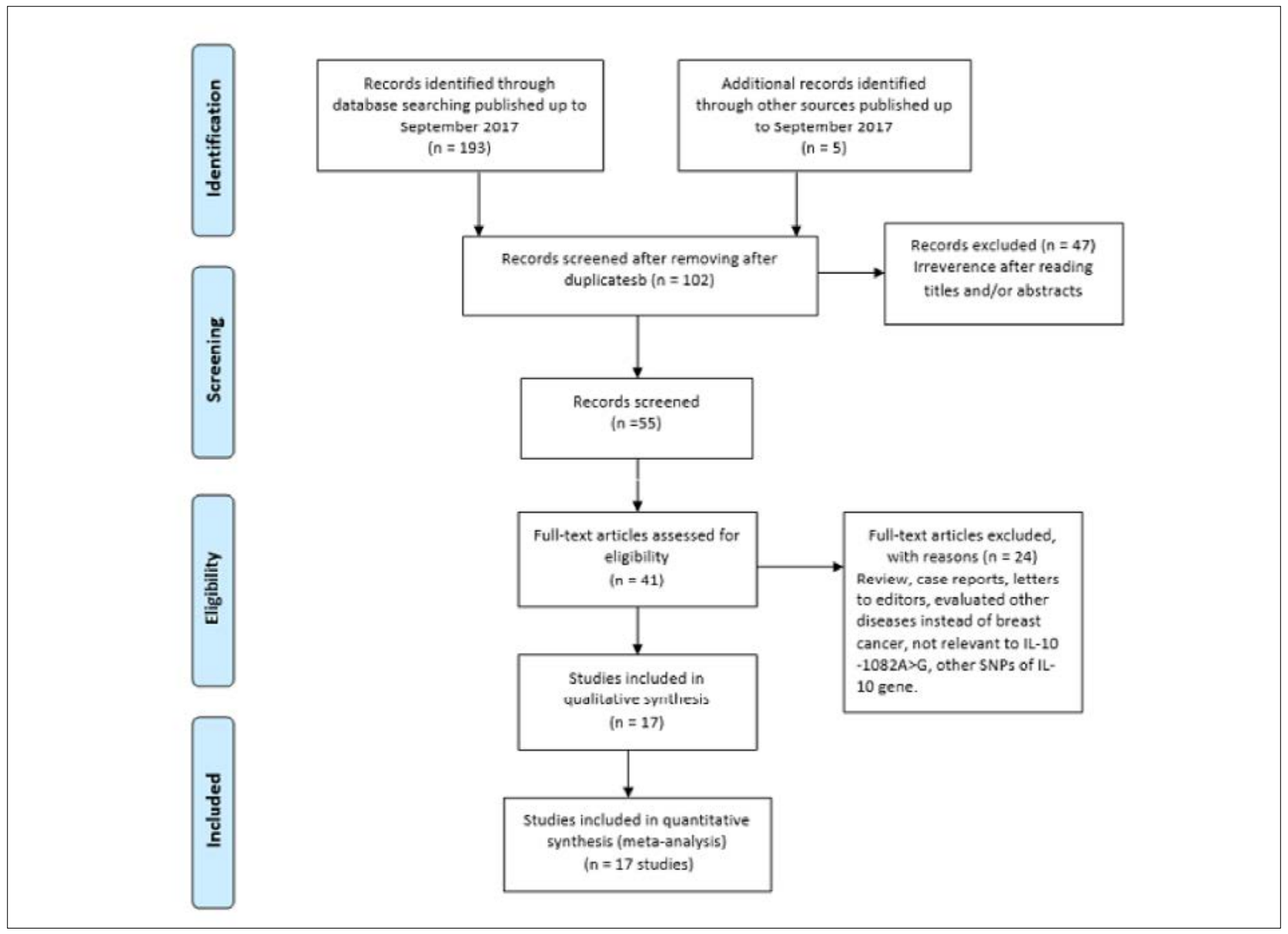


sented in Figure 1. These studies were published between 2003 and 2017 and the average sample size was 192 cases per study. Of the 17 case-control studies focusing on the relationship between IL-10 -1082A $>$ G (rs1800896) polymorphism and breast cancer, seven were conducted among Caucasians, ${ }^{15-17,18-21}$ with 1336 cases and 1388 controls, eight among Asians ${ }^{4,12,}$ 27-29,31,32 with 1,754 cases and 1,898 controls, and two among Africans, ${ }^{30,33}$ with 185 cases and 130 controls. The studies were carried out in Italy, UK, USA, Canada, Turkey, Iran, China, India, Jordan and Egypt. The detailed characteristics of the included studies were shown in Table 1. The distribution of the genotypes in the control group of five case-control studies ${ }^{13,27,30-32}$ was not in agreement with Hardy-Weinberg equilibrium (HWE). Twelve of 17 studies were in accordance with HWE were defined as high-quality studies. The genotypes distributions in the individual studies were presented in Table 1.

\section{Quantitative synthesis}

The main characteristics of these studies were listed in Table 2 . The heterogeneity between studies was significant under all genetic models. Therefore, the random effect model was used for calculating the pooled OR. Overall, there was no significant associ-

TABLE 1. MAIN CHARACTERISTICS OF STUDIES INCLUDED IN THIS META-ANALYSIS.

\begin{tabular}{|c|c|c|c|c|c|c|c|c|c|c|c|c|c|c|c|}
\hline \multirow{3}{*}{$\begin{array}{l}\text { First } \\
\text { Author/ } \\
\text { Year }\end{array}$} & \multirow{3}{*}{$\begin{array}{l}\text { Country } \\
\text { Ethnicity }\end{array}$} & \multirow[t]{3}{*}{ Case } & \multirow{3}{*}{$\begin{array}{l}\text { Con- } \\
\text { trol }\end{array}$} & \multicolumn{5}{|c|}{ Cases } & \multicolumn{5}{|c|}{ Controls } & \multirow[t]{3}{*}{ MAFs } & \multirow[t]{3}{*}{ HWE } \\
\hline & & & & \multicolumn{3}{|c|}{ Genotype } & \multicolumn{2}{|c|}{ Allele } & \multicolumn{3}{|c|}{ Genotype } & \multicolumn{2}{|c|}{ Allele } & & \\
\hline & & & & AA & AG & GG & A & G & $A A$ & $A G$ & GG & A & G & & \\
\hline $\begin{array}{l}\text { Giordani } \\
200315\end{array}$ & $\begin{array}{l}\text { Italy (Cau- } \\
\text { casian) }\end{array}$ & 125 & 100 & 60 & 54 & 11 & 174 & 76 & 33 & 51 & 16 & 117 & 83 & 0.415 & 0.614 \\
\hline $\begin{array}{l}\text { Smith } 2004 \\
16\end{array}$ & $\begin{array}{l}\text { UK (Cau- } \\
\text { casian) }\end{array}$ & 144 & 263 & 32 & 58 & 39 & 136 & 122 & 46 & 120 & 57 & 250 & 276 & 0.524 & 0.238 \\
\hline $\begin{array}{l}\text { Guzowski } \\
200517\end{array}$ & $\begin{array}{l}\text { USA (Cau- } \\
\text { casian) }\end{array}$ & 50 & 25 & 10 & 28 & 12 & 48 & 52 & 9 & 12 & 4 & 30 & 20 & 0.400 & 1.000 \\
\hline $\begin{array}{l}\text { Abdolra- } \\
\text { him-Zadeh } \\
200527\end{array}$ & $\begin{array}{l}\text { Iran } \\
\text { (Asian) }\end{array}$ & 275 & 320 & 119 & 116 & 40 & 177 & 373 & 146 & 125 & 49 & 417 & 223 & 0.348 & 0.012 \\
\hline $\begin{array}{l}\text { Balasu- } \\
\text { bramanian } \\
200618\end{array}$ & $\begin{array}{l}\text { UK (Cau- } \\
\text { casian) }\end{array}$ & 497 & 498 & 121 & 253 & 123 & 499 & 495 & 117 & 260 & 121 & 494 & 502 & 0.504 & 0.323 \\
\hline $\begin{array}{l}\text { Onay } 2006 \\
19\end{array}$ & $\begin{array}{l}\text { Canada } \\
\text { (Cauca- } \\
\text { sian) }\end{array}$ & 398 & 372 & 90 & 205 & 103 & 385 & 411 & 107 & 194 & 71 & 408 & 336 & 0.451 & 0.307 \\
\hline $\begin{array}{l}\text { Scola } 2006 \\
20\end{array}$ & $\begin{array}{l}\text { Italy (Cau- } \\
\text { casian) }\end{array}$ & 84 & 106 & 28 & 40 & 16 & 96 & 72 & 40 & 45 & 21 & 125 & 87 & 0.410 & 0.206 \\
\hline $\begin{array}{l}\text { Gonullu } \\
200721\end{array}$ & $\begin{array}{l}\text { Turkey } \\
\text { (Cauca- } \\
\text { sian) }\end{array}$ & 38 & 24 & 13 & 22 & 3 & 48 & 28 & 16 & 7 & 1 & 39 & 9 & 0.187 & 0.834 \\
\hline $\begin{array}{l}\text { Kong } 2010 \\
4\end{array}$ & $\begin{array}{l}\text { China } \\
\text { (Asian) }\end{array}$ & 315 & 322 & 285 & 29 & 1 & 599 & 31 & 285 & 35 & 2 & 605 & 39 & 0.060 & 0.422 \\
\hline $\begin{array}{l}\text { Pooja } 2012 \\
12\end{array}$ & $\begin{array}{l}\text { India } \\
\text { (Asian) }\end{array}$ & 200 & 200 & 132 & 60 & 8 & 324 & 76 & 145 & 50 & 5 & 340 & 60 & 0.150 & 0.781 \\
\hline $\begin{array}{l}\text { Liang } 2013 \\
28\end{array}$ & $\begin{array}{l}\text { China } \\
\text { (Asian) }\end{array}$ & 40 & 89 & 31 & 9 & 0 & 71 & 9 & 73 & 16 & 0 & 162 & 16 & 0.089 & 0.351 \\
\hline $\begin{array}{l}\text { Vinod } 2015 \\
29\end{array}$ & $\begin{array}{l}\text { India } \\
\text { (Asian) }\end{array}$ & 125 & 160 & 76 & 31 & 18 & 183 & 67 & 67 & 78 & 15 & 212 & 108 & 0.337 & 0.254 \\
\hline $\begin{array}{l}\text { Alsuhaibani } \\
201630\end{array}$ & $\begin{array}{l}\text { Egypt } \\
\text { (African) }\end{array}$ & 80 & 80 & 16 & 47 & 17 & 79 & 81 & 14 & 50 & 16 & 78 & 82 & 0.512 & 0.024 \\
\hline $\begin{array}{l}\text { Atoum } \\
201631\end{array}$ & $\begin{array}{l}\text { Jordan } \\
\text { (Asian) }\end{array}$ & 202 & 210 & 157 & 29 & 16 & 343 & 61 & 151 & 42 & 17 & 344 & 76 & 0.181 & 0.001 \\
\hline $\begin{array}{l}\text { Tian } 2017 \\
13\end{array}$ & $\begin{array}{l}\text { China } \\
\text { (Asian) }\end{array}$ & 312 & 312 & 51 & 132 & 129 & 234 & 390 & 27 & 154 & 131 & 208 & 416 & 0.666 & 0.050 \\
\hline $\begin{array}{l}\text { Maruthi } \\
201732\end{array}$ & $\begin{array}{l}\text { India } \\
\text { (Asian) }\end{array}$ & 285 & 285 & 80 & 146 & 59 & 262 & 308 & 89 & 159 & 37 & 234 & 336 & 0.408 & 0.009 \\
\hline $\begin{array}{l}\text { Sabet } 2017 \\
33\end{array}$ & $\begin{array}{l}\text { Egypt } \\
\text { (African) }\end{array}$ & 105 & 50 & 15 & 41 & 49 & 71 & 139 & 27 & 21 & 2 & 75 & 25 & 0.250 & 0.396 \\
\hline
\end{tabular}

MAFs: minor allele frequencies; HWE: Hardy-Weinberg equilibrium 
FIGURE 2. FOREST PLOT OF IL-10 -1082A>G POLYMORPHISM AND BREAST CANCER RISK. A: OVERALL (RECESSIVE MODEL: GG VS. GA+AA); B: ASIANS (DOMINANT MODEL: GG+GA VS. AA), C: HWE STATUS (ALLELE MODEL: GVS. A).

\section{A}

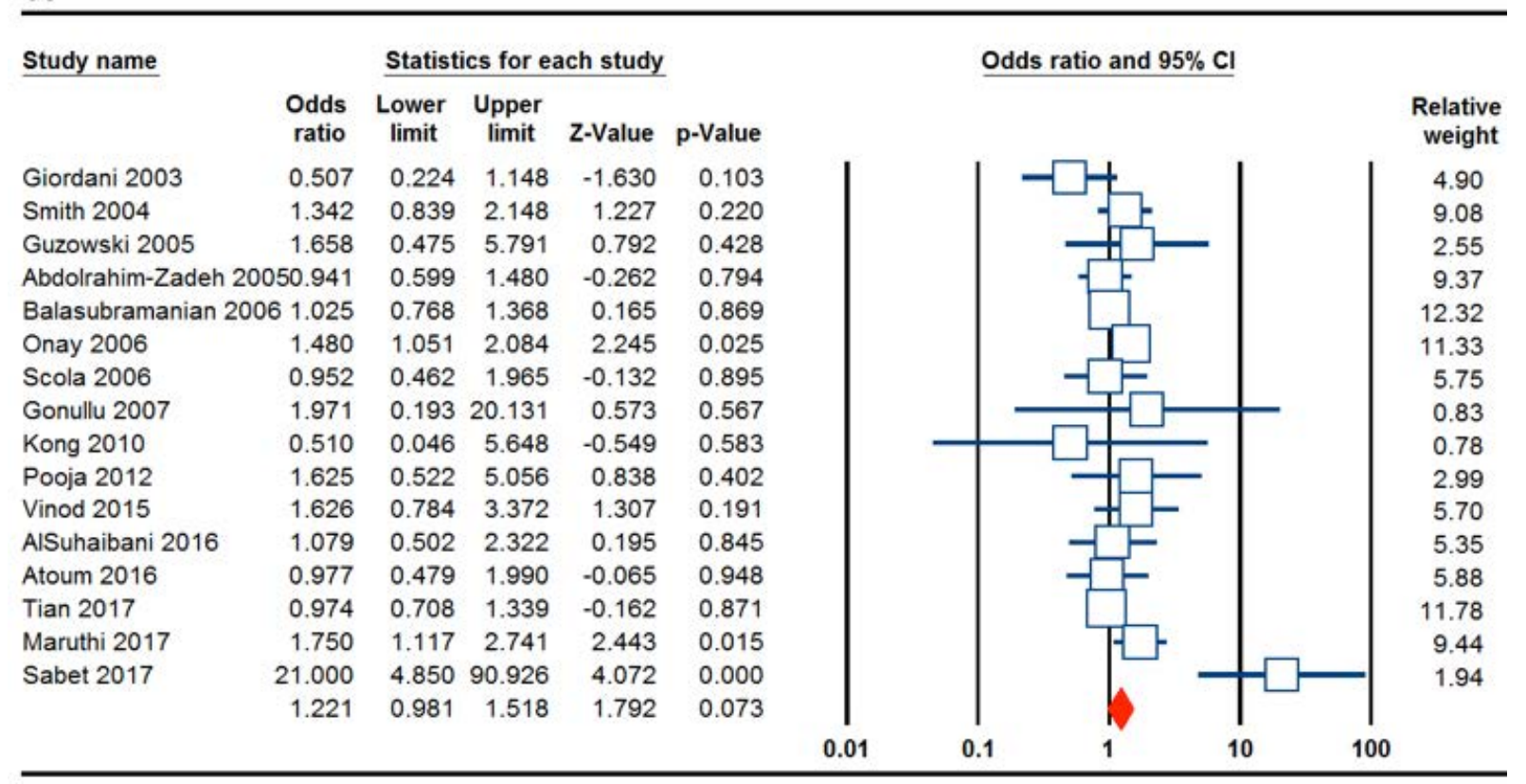

B

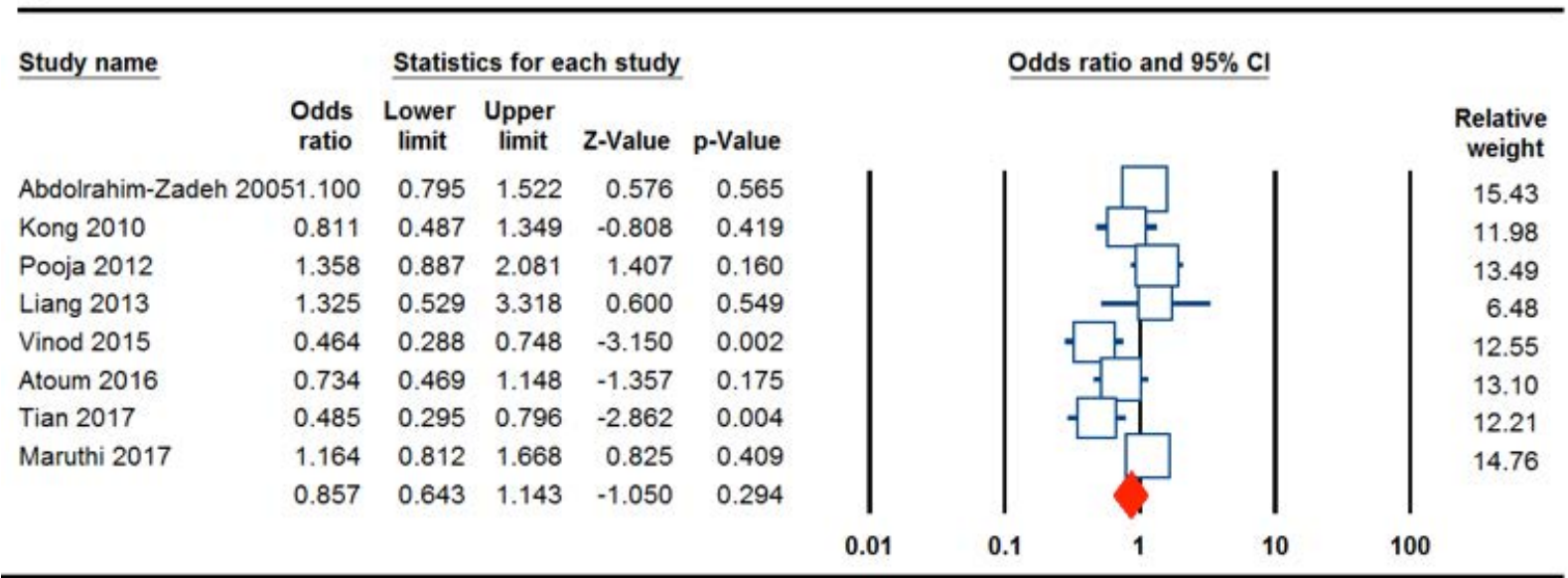

C

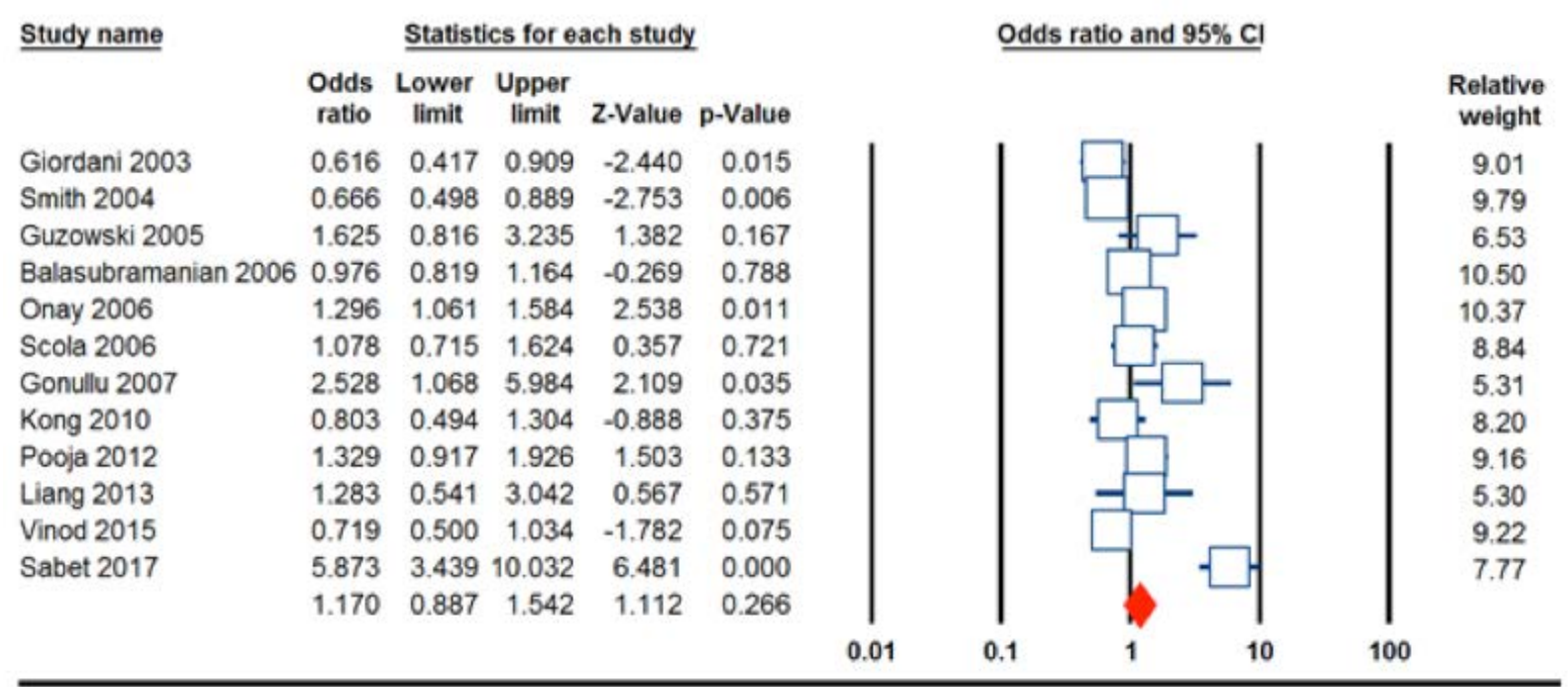


ation between the IL-10 -1082A>G (rs1800896) polymorphism and breast cancer risk under the allele model (G vs. A: $\mathrm{OR}=1.184,95 \% \mathrm{CI}=0.895-1.180, \mathrm{p}=$ 0.230), homozygote model (GG vs. AA: OR $=1.430$, $95 \% \mathrm{CI}=0.927-2.204, \mathrm{p}=0.106)$, heterozygote model (GA vs. AA: OR $=0.966,95 \% \mathrm{CI}=0.765-1.221, \mathrm{p}=$ 0.774), dominant model (GG+GA vs. AA: $\mathrm{OR}=0.957$, $95 \% \mathrm{CI}=0.697-1.314, \mathrm{p}=0.786$ ), and recessive model (GG vs. GA+AA: $\mathrm{OR}=1.221,95 \% \mathrm{CI}=0.981-1.518, \mathrm{p}=$ 0.073, Figure 2A).

We have also carried out subgroup analyses that were stratified by ethnicity. Overall, no obvious evidence of associations between the IL-10 -1082A $>\mathrm{G}$ (rs1800896) polymorphism and susceptibility to the breast cancer were found in Caucasian, Asian and African populations under all genetic models (Figure 2B). Moreover, subgroup analysis of studies with high quality (HWE status) did not show significant association between IL-10 -1082A>G (rs1800896) polymorphism and increased risk of breast cancer (Figure 2C). The results of these analyses are shown in Table 2 and Figure 2.

\section{Sensitivity Analysis}

Sensitivity analysis was performed to confirm the stability and liability of the meta-analysis by sequentially omitting individual eligible studies. When any single study was excluded, the corresponding ORs were not materially changed (data was not shown), indicating the stability of our results. Additionally, we excluded the studies that genotype distribution in the controls deviating from HWE, and the corresponding pooled ORs were not significantly changed.

\section{Publication Bias}

Table 2 and Figure 3 present information related to the publication bias. We have performed Funnel plot and Egger's linear regression to assess the publication bias of the included studies. The shapes of the funnel plots did not reveal any evidence of obvious asymmetry (Figure 3). In addition, the results of Begg's test also showed that there was no strong statistical evidence of publication bias.
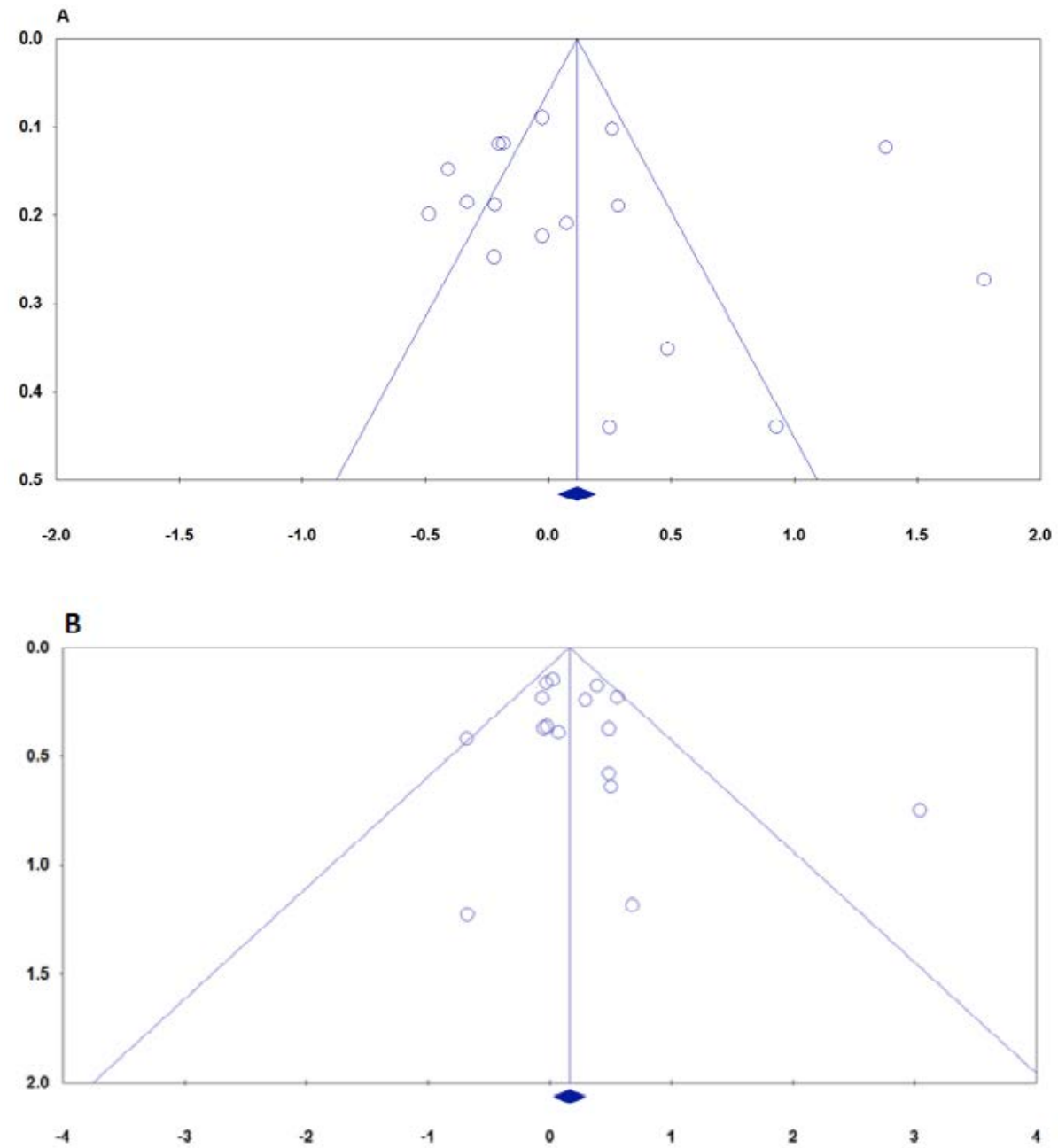

FIGURE 3. BEGG'S FUNNEL PLOTS (PUBLICATION BIAS) FOR THE ASSOCIATION BETWEEN IL-10 -1082A>G POLYMORPHISM AND RISK OF BREAST CANCER. A: ALLELE MODEL (G VS. A); B: RECESSIVE MODEL (GG VS. $G A+A A)$. 
TABLE 2. RESULTS OF META-ANALYSIS FOR RS1800896 (-1082A>G) POLYMORPHISM AND RISK OF BREAST CANCER.

\begin{tabular}{|c|c|c|c|c|c|c|c|c|c|c|}
\hline \multirow{2}{*}{$\begin{array}{l}\text { Sub- } \\
\text { group }\end{array}$} & \multirow[t]{2}{*}{ Genetic model } & \multirow{2}{*}{$\begin{array}{l}\text { Type of } \\
\text { model }\end{array}$} & \multicolumn{2}{|c|}{ Heterogeneity } & \multicolumn{4}{|c|}{ Odds ratio } & \multicolumn{2}{|c|}{ Publication Bias } \\
\hline & & & $12 \%$ & $\mathrm{PH}$ & OR & $95 \% \mathrm{Cl}$ & Ztest & POR & PBeggs & PEggers \\
\hline \multirow[t]{5}{*}{ Overall } & G vs. A & Random & 91.84 & $\leq 0.001$ & 1.184 & $0.895-1.180$ & 1.180 & 0.230 & 0.149 & 0.722 \\
\hline & GG vs. AA & Random & 80.82 & $\leq 0.001$ & 1.430 & $0.927-2.204$ & 1.617 & 0.106 & 0.843 & 0.656 \\
\hline & GA vs. AA & Random & 69.43 & $\leq 0.001$ & 0.966 & $0.765-1.221$ & -0.287 & 0.774 & 0.964 & 0.936 \\
\hline & $G G+G A$ vs. $A A$ & Random & 84.38 & $\leq 0.001$ & 0.957 & $0.697-1.314$ & -0.271 & 0.786 & 0.685 & 0.690 \\
\hline & GG vs. $G A+A A$ & Fixed & 49.63 & 0.013 & 1.221 & $0.981-1.518$ & 1.792 & 0.073 & 0.921 & 0.990 \\
\hline \multicolumn{11}{|c|}{ By Ethnicity } \\
\hline \multicolumn{11}{|c|}{ Caucasian } \\
\hline & Gvs. A & Random & 77.38 & $\leq 0.001$ & 1.018 & $0.781-1.327$ & 0.135 & 0.893 & 0.367 & 0.796 \\
\hline & GG vs. AA & Random & 83.43 & $\leq 0.001$ & 1.574 & $0.779-3.183$ & 1.264 & 0.206 & 1.000 & 0.715 \\
\hline & GA vs. AA & Random & 59.18 & 0.023 & 1.067 & $0.769-1.481$ & 0.391 & 0.696 & 0.548 & 0.413 \\
\hline & $G G+G A$ vs. $A A$ & Random & 88.89 & $\leq 0.001$ & 0.876 & $0.458-1.675$ & -0.400 & 0.689 & 0.367 & 0.935 \\
\hline & GG vs. $G A+A A$ & Fixed & 22.75 & 0.256 & 1.159 & $0.963-1.394$ & 1.561 & 0.118 & 0.763 & 0.854 \\
\hline \multicolumn{11}{|l|}{ Asian } \\
\hline & G vs. A & Random & 94.51 & $\leq 0.001$ & 1.100 & $0.670-1.805$ & 0.377 & 0.706 & 0.173 & 0.683 \\
\hline & GG vs. AA & Fixed & 50.38 & 0.060 & 1.005 & $0.784-1.286$ & 0.036 & 0.972 & 1.000 & 0.985 \\
\hline & GA vs. AA & Random & 72.47 & 0.001 & 0.803 & $0.578-1.116$ & -1.308 & 0.191 & 0.107 & 0.408 \\
\hline & $G G+G A$ vs. $A A$ & Random & 68.18 & 0.003 & 0.857 & $0.643-1.143$ & -1.050 & 0.294 & 0.536 & 0.489 \\
\hline & GG vs. GA+AA & Fixed & 14.56 & 0.319 & 1.146 & $0.937-1.403$ & 1.326 & 0.185 & 0.763 & 0.774 \\
\hline \multicolumn{11}{|l|}{ African } \\
\hline & Gvs. A & Random & 96.13 & $\leq 0.001$ & 2.377 & $0.409-13.808$ & 0.965 & 0.355 & NA & NA \\
\hline & GG vs. AA & Random & 94.09 & $\leq 0.001$ & 6.104 & $0.139-267.71$ & 0.938 & 0.348 & NA & NA \\
\hline & GA vs. AA & Random & 83.36 & 0.014 & 1.700 & $0.410-7.055$ & 0.731 & 0.465 & NA & NA \\
\hline & $G G+G A$ vs. $A A$ & Random & 92.78 & $\leq 0.001$ & 2.448 & $0.308-19.481$ & 0.846 & 0.397 & NA & NA \\
\hline & GG vs. GA+AA & Random & 91.91 & $\leq 0.001$ & 4.446 & $0.243-81.259$ & 1.006 & 0.314 & NA & NA \\
\hline \multicolumn{11}{|c|}{ High Quality Studies } \\
\hline & Gvs. A & Random & 85.14 & $\leq 0.001$ & 1.170 & $0.887-1.542$ & 1.112 & 0.266 & 0.303 & 0.397 \\
\hline & GG vs. AA & Random & 82.01 & $\leq 0.001$ & 1.842 & $0.991-3.423$ & 1.932 & 0.053 & 0.436 & 0.952 \\
\hline & GA vs. AA & Random & 73.26 & $\leq 0.001$ & 1.076 & $0.785-1.474$ & 0.455 & 0.649 & 0.537 & 0.335 \\
\hline & $G G+G A$ vs. $A A$ & Random & 88.06 & $\leq 0.001$ & 1.036 & 0.649-1.654 & 0.150 & 0.881 & 0.303 & 0.648 \\
\hline & GG vs. GA+AA & Random & 58.11 & 0.008 & 1.330 & $0.948-1.866$ & 1.648 & 0.099 & 0.876 & 0.433 \\
\hline
\end{tabular}

NA; not applicable.

\section{Minor Allele Frequency}

The present data revealed variation in the minor allele frequency of the IL-10 $-1082 \mathrm{~A}>\mathrm{G}$ polymorphism worldwide(Table 1). The minor allele frequency range was from $18.7 \%$ (Turkey) to $52.4 \%$ (UK) among Caucasians, $6 \%$ (China) to $66.6 \%$ (China) among Asians, $25 \%$ to $51.2 \%$ among Africans (Egypt).

\section{Discussion}

Previous meta-analysis by Dai et al..$^{34}$, demonstrated that IL-10 -1082A $>$ G polymorphism did not significantly associate with breast cancer risk. They have included only nine case-control studies with 1851 cases and 1910 controls on IL-10 -1082A>G polymorphism association. To further explore and examine the association of IL-10 $-1082 \mathrm{~A}>\mathrm{G}$ polymorphism with breast cancer, we conducted this meta-analysis only with most recently published studies on different populations. Compared with the previous meta-analyses, ${ }^{14}$ in this meta-analysis we have focused only on association between -10 $-1082 \mathrm{~A}>\mathrm{G}$ polymorphism and breast cancer using 17 case-controls studies with 3275 cases and 3416 controls. However, Dai et al. ${ }^{34}$ study essentially remain an open field, as meta-analysis of their results' reliability and the number of studies were considerably smaller than that needed to reach robust conclusions. Moreover, they have not included the Abdolrahim-Zadeh et al. ${ }^{27}$ study that was published in 2005 in Iran. Also, in the current meta-analysis, we have carried out subgroup analysis by ethnicity among African population. Overall, our results were consistent with Dai et al. ${ }^{34}$ results and did not show a significant relationship between IL-10 -1082A>G 
polymorphism and breast cancer. In the subgroup analysis by ethnicity, there was also no association between IL-10 -1082A $>$ G polymorphism and breast cancer risk in Caucasians, Asians and Africans.

Between-study heterogeneity is a common problem in meta-analysis for genetic association studies. ${ }^{35,36}$ In the current meta-analysis, there was a significant heterogeneity in association of IL-10 -1082A>G (rs1800896) polymorphism under all genetic models. A number of characteristics that vary among studies could be the sources of heterogeneity such as age, gender, ethnicity, sample size, including criteria, source of controls, and genotyping method. ${ }^{35,37}$ Therefore, we used meta-regression by ethnicity, which aim to reduce heterogeneity; however, we did not find any meaningful reduction in stratified analysis by ethnic and high quality studies, both of which were considered to be the relevant factors of Heterogeneity.

The main strengths of the current meta-analysis were obtaining more precise estimates, absence of publication bias, pooled data from studies from different ethnicities and sensitivity analysis indicated that our results were statistically robust. Despite these advantages, our meta-analysis also has some limitations which should be acknowledged when interpreting the results. First, the sample size was relatively small, and all data were from case-control studies. Second, we have included only studies that were published in English and Chinese languages and available full-text papers in the current meta-analysis; therefor, some eligible studies that have not been unpublished or were reported in other languages were missed, which may bias the power of our results. Third, the current meta-analysis results were based on single-factor estimates without adjustment for other risk factors such as age, gender, folate status, and specific environmental or lifestyle factors, should be conducted if possible. Finally, gene-gene, gene-environment or even the different polymorphisms of the IL-10 gene interactions were not estimated in this meta-analysis due lacking of the sufficient data.

In conclusion, our meta-analysis suggests that IL-10 -1082A>G (rs1800896) polymorphism not associated with an increased risk of breast cancer. Nevertheless, more studies are warranted to confirm the results and to establish the underlying molecular mechanisms that are involved.

\section{RESUMO}

INTRODUÇÃO: A associação entre o polimorfismo IL-10 -1082A> L (rs1800896) e o câncer da mama foi avaliada por vários estudos de casos-controle. No entanto, esses estudos podem ser insuficientes para revelar a verdadeira associação.

OBJETIVO: Efetuamos uma meta-análise abrangente para investigar a associação entre o polimorfismo IL-10 -1082A> G e câncer de mama.

MATERIAIS E MÉTODOS: Uma busca sistemática da literatura foi conduzida usando PubMed, Google Scholar e Web of Science até 20 de setembro de 2017. Os dados foram analisados com o software CMA para identificar a força da associação por proporções compartilhadas (RUP) com correspondentes intervalos de confiança de 95\% (ICS).

RESULTADOS: Um total de 17 estudos de casos-controle envolvendo 3.275 casos e 3.416 controles obtidos a partir de pesquisas de banco de dados foram examinados. Em geral, não existe uma associação significativa entre o polimorfismo IL-10 -1082A> G e o risco de câncer de mama, sob todos os modelos genéticos. Não foi encontrado nenhum viés de publicação significativo para os cinco modelos genéticos (G vs. $A: O R=1,184, I C 95 \%=0,895-1,180, p=0,230 ; G G$ vs. $A A: O R=1,430, I C 95 \%=0,927-2,204, p=0,106 ; G A$ vs. $A A: O R$ $=0,966, I C$ 95\% = 0,765-1,221, $p=0,774 ; G G+G A$ vs. AA: OR=0,957, IC 95\% = 0,697-1,314, $p=0,786$ e GG vs. GA + AA: OR=1,221, IC $95 \%=0,981-1,518, p=0,073)$. Além disso, não houve associação significativa entre o polimorfismo $I L-10-1082 A>L$ e o risco de câncer de mama por etnia.

CONCLUSÃo: Nossos resultados indicam que o polimorfismo IL-10 -1082A> G (rs1800896) não pode ser um fator de risco para o desenvolvimento de câncer de mama.

PALAVRAS-CHAVE: Neoplasias da mama. Interleucina-10. Polimorfismo genético. Metanálise.

\section{REFERENCES}

1. Gatta G, Capocaccia R, Coleman MP, Ries LA, Berrino F. Childhood cancer survival in Europe and the United States. Cancer. 2002;95(8):1767-72.

2. Wojtacki J, Lewicka-Nowak E, Lesniewski-Kmak K. Anthracycline-induced cardiotoxicity: clinical course, risk factors, pathogenesis, detection and prevention - review of the literature. Med Sci Monit. 2000;6(2):411-20.

3. Vejpongsa P, Yeh ET. Prevention of anthracycline-induced cardiotoxicity: challenges and opportunities. | Am Coll Cardiol. 2014;64(9):938-45.
4. Kalil Filho R, Hajjar LA, Bacal F, Hoff PMG, Diz MDPS, Galas FRBG, et al. I diretriz brasileira de cardio-oncologia da Sociedade Brasileira de Cardiologia. Arq Bras Cardiol. 2011;96(2 supl. 1):1-52.

5. Matos Neto RP, Petrilli AS, Silva CM, Campos Filho O, Oporto VM, Gomes LF, et al. Left ventricular systolic function assessed by echocardiography in children and adolescents with osteosarcoma treated with doxorubicin alone or in combination with dexrazoxane. Arq Bras Cardiol. 2006;87(6):763-71. 
6. Harake D, Franco VI, Henkel IM, Miller TL, Lipshultz SE. Cardiotoxicity in childhood cancer survivors: strategies for prevention and management. Future Cardiol. 2012;8(4):647-70.

7. Lipshultz SE, Sambatakos P, Maguire M, Karnik R, Ross SW, Franco VI, et al. Cardiotoxicity and cardioprotection in childhood cancer. Acta Haematol. 2014;132(3-4):391-9.

8. Ponikowski P, Voors AA, Anker SD, Bueno H, Clelan JGF, Coats AJS, et al: ESC Scientific Document Group. 2016 ESC Guidelines for the diagnosis and treatment of acute and chronic heart failure: The Task Force for the diagnosis and treatment of acute and chronic heart failure of the European Society of Cardiology (ESC)Developed with the special contribution of the Heart Failure Association (HFA) of the ESC. Eur Heart I. 2016;37(27):2129200.

9. Moher D, Liberati A, TetzlaffJ, Altman DG, The PRISMA Group. Preferred reporting items for systematic reviews and meta-analyses: the PRISMA Statement. Disponível em: www.prisma-statement.org.

10. Kalay N, Basar E, Ozdogru I, Er O, Cetinkaya Y, Dogan A, et al. Protective effects of carvedilol against anthracycline-induced cardiomyopathy. I Am Coll Cardiol. 2006;48(11):2258-62.

11. Georgakopoulos P, Roussou P, Matsakas E, Karavidas A, Anagnostopoulos $\mathrm{N}$, Marinakis T, et al. Cardioprotective effect of metoprolol and enalapril in doxorubicin-treated lymphoma patients: a prospective, parallel-group, randomized, controlled study with 36-month follow-up. Am J Hematol. 2010;85(11):894-6.

12. Kaya MG, Ozkan M, Gunebakmaz O, Akkaya H, Kaya EG, Akpek M, et al Protective effects of nebivolol against anthracycline-induced cardiomyopathy: a randomized control study. Int | Cardiol. 2013;167(5):2306-10.

13. Bosch X, Rovira M, Sitges M, Domènech A, Ortiz-Pérez IT, Caralt TM et al. Enalapril and carvedilol for preventing chemotherapy-induced left ventricular systolic dysfunction in patients with malignant hemopathies: the OVERCOME trial (preventiOn of left Ventricular dysfunction with Enalapril and caRvedilol in patients submitted to intensive ChemOtherapy for the treatment of Malignant hEmopathies). I Am Coll Cardiol. 2013;61(23):2355-62

14. Elitok $A, O z F$, Cizgici AY, Kilic L, Ciftci R, Sen F, et al. Effect of carvedilol on silent anthracycline-induced cardiotoxicity assessed by strain imaging: a prospective randomized controlled study with six-month follow-up. Cardiol ). 2014;21(5):509-15.

15. Tashakori Beheshti A, Mostafavi Toroghi H, Hosseini G, Zarifian A, Homaei Shandiz F, Fazlinezhad A. Carvedilol administration can prevent doxorubicin-induced cardiotoxicity: a double-blind randomized trial. Cardiology. 2016;134(1):47-53.

16. Jhorawat R, Kumari S, Varma SC, Rohit MK, Narula M, Suri V, et al. Preventive role of carvedilol in adriamycin-induced cardiomyopathy. Indian I Med Res. 2016;144(5):725-9.

17. Gulati G, Heck SL, Ree AH, Hoffmann P, Schulz-Menger J, Fagerland $\mathrm{MW}$, et al. Prevention of cardiac dysfunction during adjuvant breast cancer therapy (PRADA): a $2 \times 2$ factorial, randomized, placebo-controlled double-blind clinical trial of candesartan and metoprolol. Eur Heart J. 2016;37(21):1671-80

18. Swain SM, Whaley FS, Ewer MS. Congestive heart failure in patients treated with doxorubicin: a retrospective analysis of three trials. Cancer. 2003;97(1):2869-79.

19. Octavia Y, Tocchetti CG, Gabrielson KL, Janssens S, Crijns HJ, Moens AL. Doxorubicin-induced cardiomyopathy: from molecular mechanisms to therapeutic strategies. J Mol Cell Cardiol. 2012;52(6):1213-25.

20. Arola OJ, Saraste A, Pulkki K, Kallajoki M, Parvinen M, Voipio-Pulkki LM Acute doxorubicin cardiotoxicity involves cardiomyocyte apoptosis. Cancer Res. 2000;60(7):1789-92.

21. Schimmel KJ, Richel DJ, van den Brink RB, Guchelaar HJ. Cardiotoxicity of cytotoxic drugs. Cancer Treat Rev. 2004;30(2):181-91.

22. Machado V, Cabral A, Monteiro P, Gonçalves L, Providência LA. Carvedilol as a protector against the cardiotoxicity induced by anthracyclines (doxorubicin). Rev Port Cardiol. 2008;27(10):1277-96.

23. Cheng J, Kamiya K, Kodama I. Carvedilol: molecular and cellular basis for its multifaceted therapeutic potential. Cardiovasc Drug Rev. 2001;19(2):152-71.

24. Spallarossa P, Garibaldi S, Altieri P, Fabbi P, Manca V, Nasti S, et al. Carvedilol prevents doxorubicin-induced free radical release and apoptosis in cardiomyocytes in vitro. J Mol Cell Cardiol. 2004;37(4):837-46.

25. El-Shitany AN, Tolba AO, El-Shanshory RM, El-Hawary EE. Protective effect of carvedilol on adriamycin-induced left ventricular dysfunction in children with acute lymphoblastic leukemia. J Card Fail. 2012;18(8):60713.

26. Shibata MC, Flather MD, Böhm M, Borbola |, Cohen-Solal A, Dumitrascu $D$, et al; Study of the Effects of Nebivolol Intervention on Outcomes and Rehospitalisation in Seniors with heart failure (SENIORS). Rationale and design. Inter | Cardiol. 2002;86(1):77-85.

27. Münzel T, Gori T. Nebivolol: the somewhat-different beta-adrenergic receptor blocker. J Am Coll Cardiol. 2009;54(16):1491-9.

28. Groot AA, Mathy MJ, van Zwieten PA, Peters SL. Antioxidant activity of nebivolol in the rat aorta. J Cardiovasc Pharmacol. 2004;43(1):148-53.

29. Nigris F, Rienzo M, Schiano C, Fiorito C, Casamassimi A, Napoli C. Prominent cardioprotective effects of third generation beta blocker nebivolol against anthracycline-induced cardiotoxicity using the model of isolated perfused rat heart. Eur J Cancer. 2008;44(3):334-40.

30. Luna RL, Oigman W, Ramirez |A, Mion D, Batlouni M, Rocha |C, et al. Eficácia e tolerabilidade da associação bisoprolol/hidroclorotiazida na hipertensão arterial. Arq Bras Cardiol. 1998;71(4):601-8.

31. Blum RH. Clinical status and optimal use of the cardioprotectant, dexrazoxane. Oncology (Williston Park). 1997;11(11):1669-77.

32. Hellmann K. Cardioprotection by dexrazoxane (Cardioxane; ICRF 187): progress in supportive care. Support Care Cancer. 1996;4(4):305-7.

33. Fulbright |M, Huh W, Anderson P, Chandra I. Can anthracycline therapy for pediatric malignancies be less cardiotoxic? Curr Oncol Rep. 2010;12(6):411-9.

34. Iarussi D, Indolfi P, Casale F, Martino V, Di Tullio MT, Calabrò R. Anthracycline-induced cardiotoxicity in children with cancer: strategies for prevention and management. Paediatr Drugs. 2005;7(2):67-76.

35. Chatterjee K, Zhang J, Honbo N, Karliner JS. Doxorubicin cardiomyopathy. Cardiology. 2010;115(2):155-62.

36. Cvetkovic RS, Scott LJ. Dexrazoxane: a review of its use for cardioprotection during anthracycline chemotherapy. Drugs. 2005;65(7):1005-24.

37. Paiva MG, Petrilli AS, Moisés VA, Macedo CR, Tanaka C, Campos O. Cardioprotective effect of dexrazoxane during treatment with doxorubicin: a study using low-dose dobutamine stress echocardiography. Pediatr Blood Cancer. 2005;45(7):902-8.

38. Hensley ML, Hagerty KL, Kewalramani T, Green DM, Meropol NJ, Wasserman TH, et al. American Society of Clinical Oncology 2008 clinical practice guideline update: use of chemotherapy and radiation therapy protectants. J Clin Oncol. 2009;27(1):127-45

39. Pitt B, Zannad F, Remme WJ, Cody R, Castaigne A, Perez A, et al. The effect of spironolactone on morbidity and mortality in patients with severe heart failure. Randomized Aldactone Evaluation Study Investigators. N Engl J Med. 1999;341(10):709-17.

40. Akpek M, Ozdogru I, Sahin O, Inanc M, Dogan A, Yazici C, et al. Protective effects of spironolactone against anthracycline-induced cardiomyopathy. Eur J Heart Fail. 2015;17(1):81-9.

41. Meattini I, Curigliano G, Terziani F, Becherini C, Airoldi M, Allegrini $G$, et al. SAFE trial: an ongoing randomized clinical study to assess the role of cardiotoxicity prevention in breast cancer patients treated with anthracyclines with or without trastuzumab. Med Oncol. 2017:34(5):75. 